\title{
Barrier Options Model for Agricultural Commodity Price Protection
}

\author{
Gilang Primajati ${ }^{1}$, M. Najib Rodhi ${ }^{2}$, Adrian Juniarta Hidayat ${ }^{3}$ \\ ${ }^{1}$ Compter Science, Universitas Bumigora, Indonesia, e-mail : gilangprimajati@universitasbumigora.ac.id \\ ${ }^{2}$ Management, Universitas Bumigora, Indonesia, e-mail : m.najib@universitasbumigora.ac.id \\ ${ }^{3}$ Technology Information, Universitas Bumigora, Indonesia, e-mail : m.adrian@universitasbumigora.ac.id
}

\section{Article history:}

Received : 22-08-2020

Revised : 19-09-2020

Accepted : 21-09-2020

\section{Keywords:}

Brownian motion;

Barier option;

Premium;

Brown bridge motion;

Agriculture commodity

\section{ABSTRACT}

Application of barrier options for determining insurance premiums for agricultural commodity prices due to lower selling prices by applying certain barrier levels. In determining the price of insurance premiums for agricultural commodity prices such as rice, the price is assumed to follow the Brown Geometric Motion and for the determination of the barrier level line the researcher uses the Brown Bridge Motion so that there is a relationship between Bridge and Barrier. In conclusion, we obtain a model to determine the number of insurance premiums. The barrier option model approach is used to construct a fairer formula for insurance premiums on agricultural commodity prices.

This is an open access article under the CC BY-SA license.

DOI: https://doi.org/10.30812/varian.v4i1.856

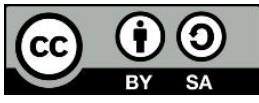

\section{A. INTRODUCTION}

According to McDonald (McDonald, 2013), derivative instruments can be defined as financial instruments in the form of agreements or contracts between two parties where the opportunities or profits are related to the underlying asset price. These basic assets can be stocks, bonds, stock indices, bond indices, currencies, interest rates, and other financial instruments (Bursa Efek Indonesia, 2010).

An option is a derivative instrument that gives an option buyer the right (not an obligation) to buy or put a particular asset to the option writer at a certain price (exercise price) within a certain period. If the expiration date of the option holder does not exercise his or her rights, then the right will be lost by itself. Thus the options it has will no longer be valuable (Higham, 2004).

According to (Fabozzi \& Markowitz, 2011), the price of an option is a reflection of the intrinsic value of the option and any additional amount over the intrinsic value. Premiums on intrinsic values are called time values or time premiums. According to (Luenberger, 1998), the option is a right, not an obligation, to buy or sell an asset at a certain price and at a set time. Options can be distinguished based on the time of execution (Wilmott et al., 1995) European Option type option, which is an option that can be used only on the due date. 2) American Option, which is an option that can be used before or on the due date. Options can reduce the risk impact by hedging, meaning that in addition to being able to buy or sell options, investors can also buy shares of those options (Black \& Scholes, 2008). 
A barrier option is an option where the payoff depends on the price of the underlying asset reaching a certain level over a certain period. That particular level is called a barrier. A barrier can also be interpreted as a condition or limitation that must be passed or not by the price of the underlying asset to be executed or the ineligible of an option contract. Barrier options are especially useful in cases of erratic or highly fluctuating stock price movements (underlying assets). Hard-to-anticipate upward and downward share price movements are necessary to create a proportionate option price. Trading barrier options is usually done regularly on the OTC (Over-The-Counter) market. The barrier option can be classified into two, namely the knock-out option and the knock-in option (Hull, 2012).

One of the biggest benefits of options is being able to provide value protection (hedging) against the risk of impairment of its underlying assets. Protection against such risks has similarities to the concept of insurance. Insurance is one way to move and reduce the risk of adverse events. The concept of options that in this case is the barrier option can be used as a basis to formulate insurance premiums in various fields. One of them is in agriculture. The relationship between the barrier option and the risk protection of an agricultural product for insurance is that the barrier option can provide a cheaper premium price because there are price restrictions for the execution of a contract. In other words, certain conditions must be met to be able to use the barrier option as an evaluation of an insurance claim (Nurmanaf et al., 2007).

Agriculture is one type of business whose risks and uncertainties are high. Sources of risk and uncertainty include the socio-economic environment, especially related to input market behavior and agricultural output, business relationship dynamics between agricultural and non-agricultural sectors, policy inconsistencies in the field of economics, social conflict, and natural environment, especially climate, natural disasters, or exploration of crop-disrupting organisms. This is compounded by the instability of commodity prices of agricultural products whose movements have been very volatile in recent years. Thus allowing the actual price of a commodity to be well below the expected price of farmers (Boer, 2012).

Based on the above background, the authors will use the application of barrier option models to protect agricultural products to protect farmers in the event of agricultural risks, namely falling rice commodity prices.

\section{B. LITERATURE REVIEW}

A barrier option is an option where the payoff depends on the underlying asset price reaching a certain level over a certain period (Hull, 2012). The barrier option is one of those exotic options that is usually traded on an over-the-counter (OTC) exchange and most of the facts are cheaper than vanilla options. Not all exotic options have path-dependent, where the option value is monitored continuously until before the time expires.

In this article the decline of the formula is done by taking references from (Subanar, 2013), (Bain \& Engelhardt, 1993)

\section{Standard Brownian Motion}

Definition 1 (Ross, 2010)

A stochastic process $\left\{W_{t}\right\}, t \geq 0$ with $W_{0}=0$ is called brown motion standard if the process meets the following criteria :

i) There is an increase in Gausian (normal) :

$$
W_{t}-W_{s} \sim N(0, t-s), 0 \leq s \leq t
$$

ii) Independent rise: $W_{t}-W_{s}$ are independent on $\sigma$-algebra

$$
\mathcal{F}_{s}=\sigma\left(W_{u}: u \leq s\right), \quad 0 \leq s \leq t ;
$$

iii) Continuous route: $W_{t}(\omega)$ continuous on $t$ for each $\omega$.

Brown's move is a Markov process. Brown's two related processes are arithmetic Brown motion and geometric Brown motion.

Definition 2 (Karatzas \& Shrev, 1988)

The arithmetic Brown motion process is provided by

$$
X_{t}=X_{0}+\mu t+\sigma W_{t}
$$


with $\mu$ and $\sigma$ is constant and $\left\{W_{t}\right\}, t \geq 0$, is a standard Brown motion.

Definition 3 (Karatzas \& Shrev, 1988)

The geometric Brown motion process is provided by the

$$
Z_{t}=\exp \left(X_{t}\right)=Z_{0} \exp \left(\mu t+\sigma W_{t}\right)
$$

with $\mu$ and $\sigma$ is constant and $\left\{W_{t}\right\}, t \geq 0$, is a standard Brown motion.

Brown's motion will be crucial when it comes to using the Black-Scholes model. Brown's motion is often referred to as the Wiener process. In general, the share price follows Brown Geometric's move

$$
S_{t}=S_{0} e^{\sigma W(t)+\left(\mu-\frac{\sigma^{2}}{2}\right) t}
$$

with $W_{t}$ is a normal distributed Brown process with zero average and t variance. It appears that $S_{t}$ is an exponent function of $W_{t}$ so that $S_{t}$ lognormal distributed.

\section{Motion Brown Bridge}

The most important basis of this research is the property of brown bridge motion because the problem is faced with a random process that has some limitation requirements, it will be very important to know the probability event that the process crosses that limit. To find the probability of such an event we will implement brown bridge ideas on barrier options.

Definition 4 (Karatzas \& Shrev, 1988) A Brown Bridge motion is a conditional Brown motion process defined as

$$
X_{t} \sim\left(W_{t} \mid W_{1}=0\right), \quad t \in[0,1],
$$

with $\left\{W_{t}\right\}$ is brown motion standard. one of the alternatives to writing the above definitions is

Definition 5 (Shreve, 2004)

Brown Bridge is a process provided by

$$
X_{t}=(1-t) W_{\frac{t}{1-t}}, t \in[0,1]
$$

\section{Result 1 :}

Known conditions in $W_{1}=0$,we can require in $W_{1}=z$, then the conditional process will be: :

$$
\left(W_{t} \mid W_{1}=z\right) \sim X_{t}+z t, t \in[0,1] \text {, }
$$

with $\left\{W_{t}\right\}$ is the Brownian bridge in definition 3.1 Similarly, we can require at two $W_{t_{1}}=z_{1}$ dan $W_{t_{2}}=z_{2}$. Then the route (trajectory) of the $W_{t}$ between the two points can be distributed as a Brown Bridge scale :

$$
\left(W_{t} \mid W_{t_{1}}=z_{1}, W_{t_{2}}=z_{2}\right) \sim z_{1} \frac{t_{2}-t}{t_{2}-t_{1}}+\sqrt{t_{2}-t_{1}} X_{\frac{t-t_{1}}{t_{2}-t_{1}}}+z_{2} \frac{t-t_{1}}{t_{2}-t_{1}}, t \in\left[t_{1}, t_{2}\right]
$$

with $\left\{X_{t}\right\}$ is Brown Bridge proces.

Note the following example.. Suppose $\left\{X_{t}\right\}$ is a Brown bridge process and $\mathrm{H}$ is a linear boundary that connects two points $\left(0, b_{1}\right)$ dan $\left(1, b_{2}\right), b_{i}>0$. The following is illustrated in Figure 1 , with the process starting at zero and being tied back to zero at $\mathrm{t}=1$, with an $\mathrm{H}$ limit on top of that process.

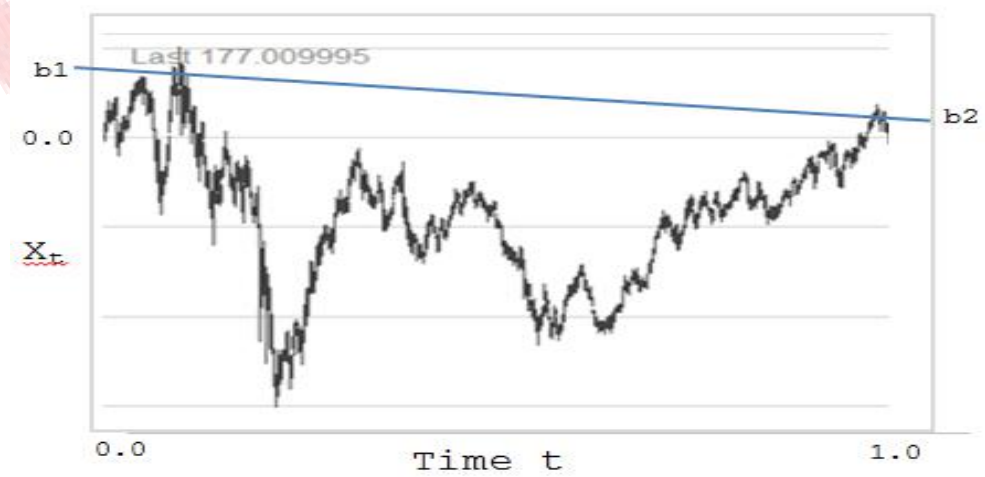

Figure 1. Examples of Brown bridge motion $X_{t}$ and Connecting Boundaries $\left(0, b_{1}\right)$ and $\left(1, b_{2}\right)$.

The probability that $\left\{X_{t}\right\}$ crosses the $H$ boundary can be written as an equation (6)

$$
P\left(X_{t}>b_{1}+\left(b_{2}-b_{1}\right) t \text {, for } t \in[0,1]\right.
$$


Based on the above definition obtained:

$$
X_{t}>b_{1}+\left(b_{2}-b_{1}\right) t \leftrightarrow(1-t) W_{\frac{t}{1-t}}>b_{1}+\left(b_{2}-b_{1}\right) t
$$

Suppose $u=\frac{t}{1-t} \leftrightarrow t=\frac{u}{1+u}$, so

$$
W_{u}>b_{1}+b_{2} u
$$

probability equivalent to

$$
\begin{aligned}
& P\left((1-t) W_{\frac{t}{1-t}}>b_{1}+\left(b_{2}-b_{1}\right) t\right) \\
& =P\left(W_{u}>b_{1}+b_{2} u ; \text { untuk suatu } \mathrm{u} \geq 0\right) \\
& =P\left(W_{u}-b_{2} u>b_{1} ; \text { untuk suatu } \mathrm{u} \geq 0\right) .
\end{aligned}
$$

but it is known that for an arithmetic Brown process with $\mu<0$ so

$$
P\left(\max _{t \geq 0}\left(\sigma W_{t}+\mu t\right)>y\right)=\exp \left(-\frac{2|\mu| y}{\sigma^{2}}\right), \quad y>0 .
$$

substitution $\mu=-b_{2}, y=b_{1}$ and $\sigma^{2}=1$ retrieved

$$
P\left(W_{u}-b_{2} u>b_{1}=\exp \left(-2 b_{1} b_{2}\right)\right.
$$

These results can be seen in Shreve dan Karatzas (1988). For example, it is now possible to find the probability that Brown $\left\{X_{t}\right\}$ remains below the barrier starting at $t_{1}>0$ and ending $t_{2}>t_{1}$. This event is depicted in figure 1 above, with the limit starting at level $h_{1}>0$ and ending at level $h_{2}>0$.

The equation in question is identical to the linear line equation of the border, namely:

$$
\left\{W_{t}<h_{1} \frac{t_{2}-t}{t_{2}-t_{1}}+h_{2} \frac{t-t_{1}}{t_{2}-t_{1}}, t \in\left[t_{1}, t_{2}\right]\right\}
$$

To find the conditional probability of a given event $W_{t_{1}}=y_{1}$ dan $W_{t_{2}}=y_{2}$,

$P\left(W_{t}<h_{1} \frac{t_{2}-t}{t_{2}-t_{1}}+h_{2} \frac{t-t_{1}}{t_{2}-t_{1}}, t \in\left[t_{1}, t_{2}\right] \mid W_{t_{1}}=y_{1}, W_{t_{2}}=y_{2}\right)$

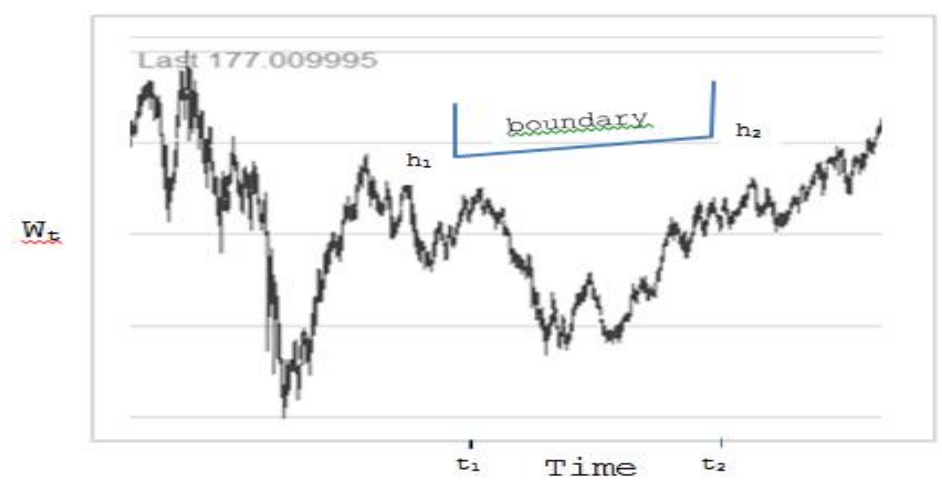

Figure 2. Brown's motion is below the line between $\left(t_{1}, h_{1}\right)$ and $\left(t_{2}, h_{2}\right)$.

Brown's motion is below the line between

$$
P\left(y_{1} \frac{t_{2}-t}{t_{2}-t_{1}}+\sqrt{t_{2}-t_{1}} X_{\frac{t-t_{1}}{t_{2}-t_{1}}}+y_{2} \frac{t-t_{1}}{t_{2}-t_{1}}<h_{1} \frac{t_{2}-t}{t_{2}-t_{1}}+h_{2} \frac{t-t_{1}}{t_{2}-t_{1}}, t \in\left[t_{1}, t_{2}\right],\right),
$$

with $\left\{X_{t}\right\}$ is Brown Bridge, using $u=\frac{t-t_{1}}{t_{2}-t_{1}}$ the probability of being

$$
P\left(X_{u}<\frac{h_{1}-y_{1}}{\sqrt{t_{2}-t_{1}}}(1-u)+\frac{h_{2}-y_{2}}{\sqrt{t_{2}-t_{1}}} u, 0 \leq u \leq 1\right)
$$

suppose $b_{1}=\frac{h_{1}-y_{1}}{\sqrt{t_{2}-t_{1}}}$ and $b_{2}=\frac{h_{2}-y_{2}}{\sqrt{t_{2}-t_{1}}}$ will be equivalent to

$$
1-P\left(X_{u}>b_{1}+\left(b_{2}-b_{1}\right) u, \quad \text { for a } u \in[0,1]\right.
$$

Based on conditional probability obtained

$$
1-\exp \left(-2 b_{1} b_{2}\right)=1-\exp \left(-\frac{2}{t_{2}-t_{1}}\left(h_{1}-y_{1}\right)\left(h_{2}-y_{2}\right)\right)
$$

So for any barrier that starts in $t_{1}$ and ends in $t_{2}$ as long as it is known $h_{1}$ and $h_{2}$, the probability of brown $W_{t}$ motion process not touching (crossing) a certain boundary can be searched using results. As for finding the probability that Brown's motion will cross a certain boundary is obtained 


$$
\exp \left(-\frac{2}{t_{2}-t_{1}}\left(h_{1}-y_{1}\right)\left(h_{2}-y_{2}\right)\right)
$$

This equation in the motion section of Brown Bridge becomes the main tool for modeling the barrier option in the next discussion.

\section{RESEARCH METHOD}

In this study used various properties of Brown's motion to create a model of agricultural insurance. The steps taken in this study are:

1. Determining the problem, i.e. the researcher collects references related to the model that the researcher will develop

2. Compare the references

3. See the advantages and disadvantages of references to then be developed refined

4. Designing agricultural insurance model by utilizing brown bridge motion

5. Analyze and discuss the models that have been developed

\section{RESULTS AND DISCUSSION}

\section{Standard Option Model for Agricultural Product Protection Insurance Premiums}

The value of the option is able to describe an expectation value of insurance premiums in the event of a claim insured by farmers namely:

$$
G\left(S_{t}\right)=E\left[\max \left(K-S_{t}, 0\right)\right]=\int_{0}^{K}\left(K-S_{t}\right) g\left(S_{t}\right) d S_{t}
$$

with

$G\left(S_{t}\right)=$ option expectation value

$K$ = future price, target price, contract price set

$S_{t}=$ random variable related to agricultural commodity price ( lognormal )

$g\left(S_{t}\right)=$ agricultural commodity probability distribution function

In this study, the price of the option can be translated as the basic premium of insurance. Agricultural insurance is unique insurance because the payment of insurance premiums usually follows the period of the agricultural production process itself, meaning the age of the option (time maturity) is equal to the production period until the harvest season arrives. The harvest season is the time to evaluate whether or not to exercise an option because the type of option used is a European model option that can only be executed at the end of the option period. Therefore the payment (purchase) of the option premium is made at present (the beginning of the growing season) and in the event of a claim then the coverage process is carried out at the end of the harvest period so that the current option value (basic premium) is

$$
P=e^{-r t} G\left(S_{t}\right)=e^{-r t} \int_{0}^{K}\left(K-S_{t}\right) g\left(S_{t}\right) d S_{t}
$$

with

$P=$ option value / price of coverage

$\mathrm{r}=$ risk-free interest rate

$\mathrm{t}=$ option life time up to execution

$g\left(S_{t}\right)=$ normal density function

The above likeness states the value of the current option to be paid for indemnification (claim) of coverage in the event of future losses. Then obtained formula to determine the insurance premium of agricultural commodity prices are:

$$
P=K e^{-r t} N\left(-h_{2}\right)-S_{0} N\left(-h_{1}\right)
$$

\section{Barrier Option Model Put Up-Out for Farm Insurance Premiums}

The payoff value of the hope to find the premium value with the barrier put-out option after the discount is written as 


$$
P_{\text {up-out }}=e^{-r T} E\left(\max \left(K-S_{T}, 0\right), S_{t}<H ; t \in[0, T]\right)
$$

due to the put-out barrier, the price of the underlying asset $\left(S_{t}\right)$ requires it to be below barrier $H$ level, starting at 0 and ending at the time of option $T$.

More simply the barrier up-out option model to determine the basic premium of an agricultural product in the event of a loss can be written as

$$
P=K e^{-r t}\left(\mathbf{N}\left(-h_{2}\right)-\left(\frac{H}{S_{0}}\right)^{2 \mu} / \sigma^{2} \mathbf{N}\left(-a_{2}\right)\right)-S_{0}\left(\mathbf{N}\left(-h_{1}\right)-\left(\frac{H}{S_{0}}\right)^{\frac{2 \mu}{\sigma^{2}}+2} \mathbf{N}\left(-a_{1}\right)\right)
$$

with

$$
\begin{aligned}
h_{1} & =\frac{\ln \left(S_{0} / K\right)+r t+0,5 \sigma^{2} t}{\sigma \sqrt{T}} \\
h_{2} & =\frac{\ln \left(S_{0} / K\right)+r t-0,5 \sigma^{2} t}{\sigma \sqrt{T}} \\
a_{1} & =\left(\frac{\ln \left(H^{2} / S_{0} K\right)+\left(r+\frac{1}{2} \sigma^{2}\right) T}{\sigma \sqrt{T}}\right) \\
a_{2} & =a_{1}-\sigma \sqrt{T} \\
\mu & =r-\frac{1}{2} \sigma^{2}
\end{aligned}
$$

\section{E. CONCLUSSION AND SUGGESTION}

Based on the results of research conducted obtained by the insurance premium model of commodity prices of agricultural products is

1. Brown Bridge motion can be used for premium price modeling of barrier options that require a level barrier to determine whether or not such options can be exercised, as standard Brown motion can be used for standard option modeling.

2. $P=K e^{-r t} \mathbf{N}\left(-h_{2}\right)-S_{0} \mathbf{N}\left(-h_{1}\right)-K e^{-r T}\left(\frac{H}{S_{0}}\right)^{2 \mu / \sigma^{2}} \mathbf{N}\left(-a_{2}\right)+S_{0}\left(\frac{H}{S_{0}}\right)^{\frac{2 \mu}{\sigma^{2}}+2} \mathbf{N}\left(-a_{1}\right)$

More simply the barrier up-out option model to determine the basic premium of an agricultural product in the event of a loss can be written as

$$
P=K e^{-r t}\left(\mathbf{N}\left(-h_{2}\right)-\left(\frac{H}{S_{0}}\right)^{2 \mu} \mathbf{\sigma ^ { 2 }} \mathbf{N}\left(-a_{2}\right)\right)-S_{0}\left(\mathbf{N}\left(-h_{1}\right)-\left(\frac{H}{S_{0}}\right)^{\frac{2 \mu}{\sigma^{2}}+2} \mathbf{N}\left(-a_{1}\right)\right)
$$

with

$$
\begin{aligned}
& h_{1}=\frac{\ln \left(S_{0} / K\right)+r t+0,5 \sigma^{2} t}{\sigma \sqrt{T}} \\
& h_{2}=\frac{\ln \left(S_{0} / K\right)+r t-0,5 \sigma^{2} t}{\sigma \sqrt{T}} \\
& a_{1}=\left(\frac{\ln \left(H^{2} / S_{0} K\right)+\left(r+\frac{1}{2} \sigma^{2}\right) T}{\sigma \sqrt{T}}\right) \\
& a_{2}=a_{1}-\sigma \sqrt{T}
\end{aligned}
$$

for the barrier up-out option insurance premium model. 


\section{ACKNOWLEDGEMENTS}

Researchers would like to thank the Universitas Bumigora for giving permission to collaborate in the field of research and provide moral support, so that this research can be carried out well.

\section{REFERENCES}

Bain, L. J., \& Engelhardt, M. (1993). Introduction to Probability and Mathematical Statistics. Duxbury Press.

Black, F., \& Scholes, M. (2008). The pricing of options and corporate l. The Journal of Political Economy, 81(3), 637-654.

Boer, R. (2012). Asuransi Iklim Sebagai Jaminan Perlindungan Ketahanan Petani Terhadap Perubahan Iklim. Prosiding Widyakarya Nasional Pangan Dan Gizi 10: Pemantapan Ketahanan Pangan Dan Perbaikan Gizi Berbasis Kemandirian Dan Kearifan Lokal.

Bursa Efek Indonesia. (2010). Buku Panduan Indeks Harga Saham Bursa Efek Indonesia. Indonesia Stock Exchange Building.

Fabozzi, F. J. ., \& Markowitz, H. M. (2011). The Theory and Practice of Investment Management. John Wiley \& Sons, Inc.

Higham, D. J. (2004). An Introduction to Financial Option Valuation. Cambridge University Press.

Hull, C. J. (2012). Options, Futures, and Other Derivatives. Person Education.

Karatzas, I., \& Shrev, S. E. (1988). Brownian Motion and Stochastic Calculus. Springer-Verlag.

Luenberger, D. G. (1998). Investment Science. Oxford University Press.

McDonald, R. L. (2013). Derivatives Markets. In Journal of Chemical Information and Modeling. Library of Congress Cataloging.

Nurmanaf, A. R., Sumaryanto, Wahyuni, S., Ariningsih, E., \& Supriyatna, Y. (2007). Analisis Kelayakan dan Perspektif Pengembangan Asuransi Pertanian pada Usahatani Padi dan Sapi Potong.

Ross, S. M. (2010). Introduction to Probability Models. Academic Press is an Imprint of Elsevier.

Subanar, P. D. P. . (2013). Statistika Matematika Probabilitas, Distribusi, dan Asimtotis dalam Statistika. Graha Ilmu.

Wilmott, P., Howison, S., \& Dewynne, J. (1995). The Mathematics of Financial Derivatives_A Student Introduction (p. 339). Cambridge University Press. 
78 | Jurnal Varian| Vol. 4, No. 1, Oktober 2020, Hal. 71-78 